\title{
Agro-Environmental Evaluation of Irrigation Water from Different Sources, Together with Drainage and Escape Water of Rice Irrigation Systems, According to its Impact on Maize (Zea mays L.)
}

\author{
Pavlo Lykhovyd ${ }^{1 *}$, Olha Dementiieva ${ }^{2}$, Sergiy Lavrenko², Nataliia Lavrenko \\ 1 Institute of Irrigated Agriculture of the National Academy of Agrarian Sciences of Ukraine, Naddniprianske, \\ 73483, Kherson, Ukraine \\ 2 Kherson State Agricultural University, Stritenska Street 23, 73006, Kherson, Ukraine \\ * Corresponding author's e-mail: pavel.likhovid@gmail.com
}

\begin{abstract}
The water supply deficit requires agro-environmental rationale for the use of alternative water sources to feed agricultural crops, viz.: industrial wastes, municipal drains, farm animal waste, drainage and escape water of rice irrigation systems. We analyzed the quality of irrigation water from different sources, with regard to the content of cations, anions, water-soluble salts, power of hydrogen $(\mathrm{pH})$, sodium adsorption ratio (SAR), etc. in it. In the course of the greenhouse trial, we diagnosed its impact on the indicator crop (maize) (Zea mays L.) with its herbage crop stage of 10 leaves, supplied with water of varying quality. We proved the viability of improved drainage and escape water from rice irrigation systems in irrigated agriculture, owing to which maize herbage was diminished, on average, by $5.82 \%$. We verified the negative impact of irrigation water, which contains the effluent disposals of metallurgical production, on croppers - it had contributed to diminishing the watered maize herb, on average, by $39.27 \%$. A correlation analysis of the test data proved the closely interrelated feedback between the maize herbage amount and the content of cations, anions and water-soluble salts in irrigation water (coefficient of correlation $r$ varied between 0.88 and 0.98 ). The worked-out linear regressive model for maize herbage, based on the content of water-soluble salts in irrigation water, together with SAR index $\left(Y=2342.71-1.82 \times x_{1}+366.78 \times x_{2}\right)$, affirmed the validity of the pattern, discovered by means of the correlation analysis.
\end{abstract}

Keywords: maize, irrigation water quality, regression model, drainage and escape water from rice irrigation systems, effluent disposals of metallurgical production.

\section{INTRODUCTION}

Irrigation is the prime instrument used to intensify crop production in the areas lacking natural moistening. The deficiency and low quality of irrigation water requires solution to a number of auxiliary issues, and among other things, the use of irrigation water from different sources: reusing drainage and escape water from rice irrigation systems; municipal drains along with industrial effluents - to enhance the efficient utilization of aquatic resources and reduce the environmental impact (Cui et al., 1998; Li, 2001; Oron et al., 1999; Lu, 2000; Tarjuelo et al., 2010).
The use of irrigation water from different sources, especially drainage and escape water from rice irrigation systems, in agriculture, requires examining its influence on agroecosystems in detail. The aim of the research involved specifying the agronomical value of water from different water facilities, including the water contaminated by effluent disposals of metallurgical production, as well as drainage and escape water from rice irrigation systems. We have put forward a hypothesis, concerning a possibility to safely use drainage and escape water from rice irrigation systems for watering agricultural crops, provided that it is improved by being diluted with the 
Dnipro river water at the ratio of $3: 1$. The irrigation water was evaluated according to its content of water-soluble salts, power of hydrogen, SAR index, as well as its influence on the indicator crop (maize) (Zea mays L.). The appraisal of irrigation water quality was determined by its influence on the crop, with its herbage comprising 10 leaves at that stage of development.

\section{MATERIALS AND METHODS}

A greenhouse trial to study the influence of irrigation water of miscellaneous quality on maize crops was performed each year from 2012 to 2015, within the period from September to October, at the vegetation house of the Public Higher Education Institution "Kherson State Agricultural University" (Kherson city, Ukraine) in four replications. The scientific research involved the study of such variants:

- Variant 1. The Krasnoznamianka irrigation system water $(100 \%)$ - standard water of the Dnipro River;

- Variant 2. The Ingulets irrigation system water $(100 \%)$ - water comprised by effluent disposals of metallurgical production and improved by the Dnipro River water;

- Variant 3. Improved drainage and escape water of rice irrigation systems $(75 \%$ of the Dnipro River water $+25 \%$ of drainage and escape water of rice irrigation systems);

- Variant 4. Drainage and escape water of rice irrigation systems (100\%).

The irrigation water samples for watering crops were taken with the volume of 10 litres in four replications in pure plastic containers from irrigation systems mains: Ingulets (latitude $47^{\circ} 0{ }^{\prime} 55^{\prime} \mathrm{N}$ and longitude $32^{\circ} 47^{\prime} 20$ ' $\mathrm{E}$ ), Krasnoznamianka (latitude $46^{\circ} 17^{\prime} 1^{\prime \prime} \mathrm{N}$ and longitude $\left.33^{\circ} 8^{\prime} 8^{\prime \prime} \mathrm{E}\right)$, as well as drainage and escape water of the rice irrigation systems of the Institute of Rice of the National Academy of the Agrarian Sciences of Ukraine (latitude $46^{\circ} 08^{\prime} 34^{\prime \prime} \mathrm{N}$ and longitude $\left.32^{\circ} 57^{\prime} 15^{\prime \prime} \mathrm{E}\right)$. The water of the Ingulets irrigation system is systematically contaminated by the effluent disposals of metallurgic production of the Kryvbas (latitude 47 $56^{\prime} 07^{\prime \prime} \mathrm{N}$ and longitude $33^{\circ} 03^{\prime} 40^{\prime} \mathrm{E}$ ), and improved by mixing with the water of the Dnipro River (Lykhovyd and Kozlenko, 2018). The source of water for the Krasnoznamianka irrigation system is the
Dnipro River. The selected water samples were mixed proportionally under laboratory conditions to comply with the experiment scheme. The salt content in the irrigation water was established by the generally accepted procedure (APHA, 1995). Hydrogen power $(\mathrm{pH})$ was measured by a $\mathrm{pH}$ meter. $\mathrm{Ca}^{2+}$ and $\mathrm{Mg}^{2+}$ cations concentrations were established through ethylenediaminetetraacetic acid titration. $\mathrm{Na}^{+}$cations concentrations were established by means of a flame photometer. The $\mathrm{Cl}^{-}$ anions concentrations were established through silver nitrate titration. The $\mathrm{HCO}_{3}{ }^{-}$and $\mathrm{CO}_{3}{ }^{2-}$ concentrations were established through hydrochloric acid titration. The $\mathrm{SO}_{4}^{2-}$ cations concentrations were established through barium chloride titration. The sodium adsorption ratio was calculated according to Eq. (1):

$$
S A R=\mathrm{Na}^{+} / \sqrt{ } 0.5 \times\left(\mathrm{Ca}^{2+}+\mathrm{Mg}^{2+}\right)
$$

where: $S A R$ is sodium adsorption ratio in me/l; $\mathrm{Na}^{+}, \mathrm{Ca}^{2+}, \mathrm{Mg}^{2+}$ is cations content in me/l.

Each variant of the experiment was presented by four vegetation vessels. The vegetation vessel had the form of a plastic cylinder with the volume of $0.017 \mathrm{~m}^{3}$ (height $-0.55 \mathrm{~m}$, diameter $-0.20 \mathrm{~m}$ ). The vegetation vessel was filled with dark chestnut middle loamy soil of undestroyed composition, weighing $10 \mathrm{~kg}$. Humus level was $2.5 \%$, bulk density $-1.29 \mathrm{t} / \mathrm{m}^{3}$, minimal field capacity $-20.8 \%$. The content of alkaline hydrolyzed nitrogen in soil was 35 , labile phosphorus -32 , changeable potassium $-430 \mathrm{mg} / \mathrm{kg}$. In each vegetation vessel, 5 maize crops of Tendra hybrid (FAO 190) were grown. The dropping was done in manual way to the depth of $5 \mathrm{~cm}$ on September $1^{\text {st }}$. Maize watering maintained the moisture content of the soil in the vegetation vessels in the active layer of $0-50 \mathrm{~cm}$ with $75 \%$ of minimal field capacity. The moisture content of the soil was monitored by means of the Rapitest 1825 moisture meter. The water application rate was calculated according to Eq. (2):

$$
m=100 \times h \times d c \times(R-r)
$$

where: $m$ is water application rate, $\mathrm{m}^{3} / \mathrm{ha}$;

$h-$ active layer $(0-50 \mathrm{~cm})$;

$d c$ - active layer bulk density $\left(1.29 \mathrm{t} / \mathrm{m}^{3}\right)$; $R$ - minimal water capacity of the active layer (20.8\%);

$r$ - pre-irrigation threshold (75 percent of minimal water capacity). 
The water application rate, meant for the conditions of greenhouse trial, amounted to 1050 $\mathrm{ml}$ of water per vegetation vessel. The watering was executed with a watering vessel on the edges. During the experiments 2 waterings were carried out in keeping with the above-mentioned norm within 23-24 days and nights. The temperature of the air in the vegetation house during this entire period of experiments was at the level of $22-25^{\circ} \mathrm{C}$, the degree of air saturation - at the level of $70-75 \%$. The influence of the irrigation water on maize was established according to the formed maize herbage at the stage of 10 leaves, by cutting it and weighing it on an analytical balance, in the first third of October. The mathematical treatment of the obtained experiment data, carried out by means of analysis of variance, as well as correlation and regression analyses, was performed with LibreOffice Calc 5.4 and PSPP 1.01. software. The regression analysis of the data was performed according to the least squares method. The equation of linear regressive model of the form $y=a+b x_{1}+c x_{2}$ was composed, consistent with the values of the calculated coefficients of regression and absolute term.

\section{RESULTS}

\section{A Quality Analysis of Irrigation Water from Different Sources}

The results of laboratory analyses of irrigation water from different sources are specified in Table 1.

It was established that the $\mathrm{pH}$ value for irrigation water from all the sources in question did not exceed the maximum permissible limits. At the same time, the $\mathrm{pH}$ value of the water from the Krasnoznamianka and the Ingulets irrigation systems, which tended to the upper bound, as determined by FAO standards, was equal to 8.40 (Ayers and Westcott, 1985). The minimum recorded $\mathrm{pH}$ value in the rice irrigation systems drainage and escape water was 7.80. The irrigation water from all the sources in question was described as alkaline, able to increase the $\mathrm{pH}$ of soil solution, and, in specific situations, interfere with normal growth and development of tender cultivated plants.

The maximum total content of water-soluble salts was recorded in the water of the Ingulets irrigation system $-1563.00 \mathrm{mg} / \mathrm{l}$, suggestive of its limited applicability for irrigation. Apart from that the Ingulets irrigation system water was marked by maximum total content of toxic and dangerous ions: $\mathrm{Cl}^{-}(9.20 \mathrm{me} / \mathrm{l}$ in view of the upper permissible limit of $10.00 \mathrm{me} / \mathrm{l}), \mathrm{Na}^{+}(12.11 \mathrm{me} / \mathrm{l}$ in view of the optimal values of 3-9 me/l), $\mathrm{HCO}_{3}^{-}$ (3.88 me/1, which is within tolerance for marginally applicable irrigation water $-1.5-8.5 \mathrm{me} / \mathrm{l}$ ). The minimum content of water-soluble salts was found in the Krasnoznamianka irrigation system water $-379.00 \mathrm{mg} / \mathrm{l}$, which enabled to classify it under this value with those applicable for irrigation without restraint (mineralization $<450$ $\mathrm{mg} / \mathrm{l})$. Slightly higher values of the index were found in the drainage and escape waters of rice irrigation systems $(695.00 \mathrm{mg} / \mathrm{l})$ and mixed irrigation water $(467.30 \mathrm{mg} / \mathrm{l})$, which, as indicated by its water-soluble salts content, pertain to those limitedly applicable for irrigation (mineralization $450-2000 \mathrm{mg} / \mathrm{l}$ ). The irrigation water from all the sources in question, except the Ingulets irrigation system, was recorded as having a content of toxic cations and anions, which allows absolute applicability for irrigation water, save for hydrocarbonate ions that are $1.31 \mathrm{me} / \mathrm{l}$ above the standard in the Krasnoznamianka irrigation system water, $1.60 \mathrm{me} / \mathrm{l}$ above the standard in mixed water, and $2.29 \mathrm{me} / \mathrm{l}$ above the standard in the drainage and escape water of rice irrigation systems.

The proportion of nitrate ions, phosphate ions, ammonia nitrogen in all the irrigation water in question was within the optimum. The maximum nitrate ions content $(2.22 \mathrm{mg} / \mathrm{l})$ was recorded in the rice irrigation system drainage and escape water, suggestive of its low nutritional value: out of $1000 \mathrm{~m}^{3}$ of such water, only $2.22 \mathrm{~kg}$ of assimilable nitrate nitrogen will deposit on the plants in the field.

An agronomic evaluation of irrigation water quality by the integrative factor of its sodium adsorption ratio, suggestive of a probability of secondary salinization and alkalinization of soil under the influence of irrigation water, confirmed the safety of the irrigation water from all the sources (SAR close to $1.00 \mathrm{me} / \mathrm{l}$ ), but not including the Ingulets irrigation system (SAR being $4.70 \mathrm{me} / \mathrm{l}$ ).

Below is the irrigation water categorization according to its irrigation fitness in descending order:

1) The Krasnoznamianka irrigation system water;

2) Mixed water ( $75 \%$ of the Krasnoznamianka irrigation system water $+25 \%$ of rice irrigation systems drainage and escape water); 
Table 1. Quality factors for irrigation water from different sources

\begin{tabular}{|l|c|c|c|c|}
\hline \multirow{2}{*}{ Quality factors } & \multicolumn{3}{|c|}{ Irrigation water quality factor values } \\
\cline { 2 - 5 } & Variant 1 & Variant 2 & Variant 3 & Variant 4 \\
\hline Power of Hydrogen $\mathrm{pH}$, units & $8.30 \pm 0.08$ & $8.28 \pm 0.02$ & $8.10 \pm 0.09$ & $7.80 \pm 0.09$ \\
\hline Water-soluble salts content, $\mathrm{mg} / \mathrm{l}$ & $379.00 \pm 12.20$ & $1563.00 \pm 23.20$ & $467.30 \pm 17.20$ & $695.00 \pm 25.30$ \\
\hline \multirow{2}{*}{ Hydrocarbonates, $\mathrm{mg} / \mathrm{l}(\mathrm{me} / \mathrm{l})$} & $168.40 \pm 15.90$ & $232.80 \pm 12.20$ & $186.00 \pm 27.40$ & $228.00 \pm 16.40$ \\
& $(2.81 \pm 0.83)$ & $(3.88 \pm 0.44)$ & $(3.10 \pm 0.91)$ & $(3.79 \pm 0.55)$ \\
\hline \multirow{2}{*}{ Sulphates, mg/l (me/l) } & $82.00 \pm 14.00$ & $485.30 \pm 11.10$ & $94.00 \pm 14.90$ & $122.50 \pm 10.40$ \\
& $(1,71 \pm 0.58)$ & $(10.11 \pm 0.54)$ & $(1.96 \pm 0.62)$ & $(2.55 \pm 0.43)$ \\
\hline Chlorides, mg/l (me/l)) & $40.80 \pm 7.30$ & $326.50 \pm 9.70$ & $45.10 \pm 7.70$ & $52.60 \pm 9.90$ \\
& $(1.15 \pm 0.41)$ & $(9.20 \pm 0.54)$ & $(1.27 \pm 0.44)$ & $(1.48 \pm 0.56)$ \\
\hline Calcium, mg/l (me/l) & $44.20 \pm 3.20$ & $115.20 \pm 5.20$ & $47.00 \pm 3.40$ & $51.70 \pm 0.80$ \\
& $(2.21 \pm 0.32)$ & $(5.76 \pm 0.97)$ & $(2.35 \pm 0.35)$ & $(2.58 \pm 0.08)$ \\
\hline Magnesium, mg/l (me/l) & $24.30 \pm 6.50$ & $89.00 \pm 3.50$ & $29.00 \pm 6.90$ & $40.90 \pm 5.20$ \\
& $(2.03 \pm 1.08)$ & $(7.42 \pm 1.26)$ & $(2.42 \pm 1.15)$ & $(3.41 \pm 0.84)$ \\
\hline Sodium, mg/l (me/l)) & $32.90 \pm 6.80$ & $279.00 \pm 25.70$ & $36.00 \pm 4.90$ & $40.80 \pm 1.80$ \\
& $(1.43 \pm 0.59)$ & $(12.11 \pm 2.23)$ & $(1.57 \pm 0.42)$ & $(1.77 \pm 0.15)$ \\
\hline Ammonia nitrogen, mg/l & $0.15 \pm 0.01$ & $0.23 \pm 0.03$ & $0.21 \pm 0.01$ & $0.33 \pm 0.04$ \\
\hline Nitrate ions, mg/l & $0.99 \pm 0.07$ & $1.38 \pm 0.01$ & $1.36 \pm 0.07$ & $2.22 \pm 0.03$ \\
\hline Phosphate ions, mg/l & $0.12 \pm 0.01$ & $0.13 \pm 0.02$ & $0.18 \pm 0.02$ & $0.29 \pm 0.05$ \\
\hline SAR, me/l & $1.01 \pm 0.46$ & $4.70 \pm 0.64$ & $1.04 \pm 0.33$ & $1.03 \pm 0.14$ \\
\hline
\end{tabular}

Note: Quality factors are shown on average for the observations from 2012 to $2015 \pm$ SD (standard deviation).

3) Rice irrigation systems drainage and escape water;

4) The Ingulets irrigation system water.

\section{Irrigation Water Agronomic Evaluation by its Influence on Maize}

Maize herbage at the observed crop stage of 10 leaves is shown in Table 2.

Variance analysis of the results showed significant difference among all the variants in question. A considerably higher maize herbage yield from the vegetation vessel was ensured by the Krasnoznamianka irrigation system water from the Dnipro River (Variant 1) - $2.009 \mathrm{~kg}$. The minimal value of the index was obtained when the crop was moistened with the Ingulets irrigation system water, contaminated by effluent disposals of metallurgic production $-1.220 \mathrm{~kg}(39.27 \%$ less than in Variant 1). The rice irrigation systems drainage and escape waters also reduced the crop's yield to a substantial degree (1.450 $\mathrm{kg}$ of herbage was formed under the variant, or $27.82 \%$ less than in Variant 1), but less significantly, compared to the Ingulets irrigation system water. When the rice irrigation systems water was diluted with that of the Dnipro River at the ratio $1: 3$, the crop yield was only $5.82 \%$ less, suggestive of potential use of such water for irrigation practically without restriction.

\section{Regression Model of Maize Herbage Subject To the Basic Cations and Anions Content in Irrigation Water}

A correlation analysis of relationship between corn herbage and concentration of basic cations and anions in irrigation water made it clear that increasing their ratio leads to decreasing the crop growth and development conditions. The correlation analysis showed strong correlation of the elements in question $(0.78-0.98)$ in the opposite direction. Interestingly, the hydrocarbonate ions influence proved to be the most toxic when the coefficient of determination equalled 0.96 (Table 3 ).

It was established by correlation analysis of the experimental findings that the maize herbage practically did not depend on the power of Hydrogen of the irrigation water - coefficient of correlation amounted to 0.21 ; coefficient of de-

Table 2. Maize herbage at crop stage of 10 leaves in one vegetation vessel, $\mathrm{kg}$

\begin{tabular}{|c|c|c|c|c|}
\hline Variants & Variant 1 & Variant 2 & Variant 3 & Variant 4 \\
\hline Herbage & $2.009 \pm 0.125$ & $1.220 \pm 0.101$ & $1.892 \pm 0.082$ & $1.450 \pm 0.088$ \\
\hline
\end{tabular}

Note: Maize herbage is shown on average during the observations from 2012 to $2015 \pm$ SD (standard deviation). The LSD (least significant difference) of observation data variance analysis for some years was $0.077 \mathrm{~kg}$ (the difference among all the variants is significant at $\mathrm{p}<0.05$ ). 
Table 3. Coefficient of correlation and coefficient of determination of maize herbage in one vegetation vessel with irrigation water quality indicators

\begin{tabular}{|l|c|c|}
\hline \multicolumn{1}{|c|}{ Water quality indicators } & Coefficient of correlation $r$ & Coefficient of determination $r^{2}$ \\
\hline Hydrocarbonates, me/l & -0.98 & 0.96 \\
\hline Sulphates, me/l & -0.81 & 0.66 \\
\hline Chlorides, me/l & -0.78 & 0.61 \\
\hline Calcium, me/l & -0.81 & 0.66 \\
\hline Magnesium, me/l & -0.89 & 0.79 \\
\hline Sodium, me/l & -0.78 & 0.61 \\
\hline Water-soluble salts content, $\mathrm{mg} / \mathrm{l}$ & -0.88 & 0.77 \\
\hline Power of Hydrogen $(\mathrm{pH})$, units & 0.21 & 0.04 \\
\hline SAR, me/l & -0.76 & 0.58 \\
\hline
\end{tabular}

termination - 0.04. Consequently, this indicator is not defining, same as water-soluble salts content (coefficient of correlation 0.88 ; coefficient of determination - 0.77) and SAR (coefficient of correlation 0.76 ; coefficient of determination - 0.58), all being in close inverted correlation with maize herbage.

The findings of regression analysis, showing the dependence of maize herbage in a vegetation vessel on the water-soluble salts content in irrigation water, and SAR, are shown in Table 4.

Linear regression model for the quantity of formed maize herbage $(Y)$, subject to the content of water-soluble salts in irrigation water and $\mathrm{SAR}$, in relation with the estimated coefficients of regression and free term, is as follows:

$$
Y=2342.71-1.82 \times x_{1}+366.78 \times x_{2} .
$$

The value of multiple correlation coefficient $R$, tending to 1.00 , of actual calculated Fisher's variance ratio, superior to the theoretical critical value, as well as evaluation, determined by the predicted values of maize herbage, point to the high precision and effectiveness of the elaborated linear regression model (Table 5).

\section{DISCUSSION}

Scientific studies prove that long-lasting irrigation with saline water, high in $\mathrm{Na}^{+}$cations, $\mathrm{HCO}_{3}{ }^{-}$anions, $\mathrm{CO}_{3}{ }^{2-}, \mathrm{Cl}^{-}$, without appropriate melioration measures taken, impairs soil, leads to significant deterioration of its hydrological, physical, chemical properties, weakening of beneficial soil biota, etc. (Wilcox, 1955; Kelly, 1963; Ayers and Westcott, 1985; Ould Ahmed et al., 2007). Consequently, there is a decline in the crops yield and quality (Wan et al., 2007; Rengasamy, 2010; Wan et al., 2010; Wang et al., 2015). The findings of our vegetation trial revealed significant maize herbage decline amid the growth of water-soluble salts and toxical ions in irrigation water. Similar results were obtained by a number of researchers during the time when they studied the impact of poor quality water irrigation on the yield and quality of tomatoes (Banjaw et al., 2017), pepper (Rameshwaran et al., 2015), lettuce (Andriolo et al., 2015), Chinese cabbage (Kim et al., 2016), grain sorghum (Ould Ahmed et al., 2007), safflower (Feizi et al., 2010), etc. At the same time, we would also like to mention alternative results, obtained by some scholars. Among other things, when they studied special aspects of crops behav-

Table 4. Findings of regression analysis showing dependence of maize herbage in vegetation vessel on water-soluble salts content of irrigation water and its SAR

\begin{tabular}{|l|l|}
\hline To which of $x$ findings belong & $\begin{array}{l}\text { Free term } a \text { and coefficients } \\
\text { of regression } b\end{array}$ \\
\hline$x_{1} x_{2}$ & 2342.71 \\
\hline $\begin{array}{l}\text { Water-soluble salts content, } \\
\text { mg/l }\left(x_{1}\right)\end{array}$ & -1.82 \\
\hline SAR, me/l $\left(x_{2}\right)$ & 366.78 \\
\hline
\end{tabular}

Note: Multiple correlation coefficient $\mathrm{R}$ amounted to 0.99; Fisher's variance ratio F was 359.03 (abstract critical value of Fisher's variance ratio $\mathrm{Ft}$ at $\mathrm{p}<0.05$ is 199.50, hence $\mathrm{F}>\mathrm{Ft}$ ).

Table 5. Maize herbage quantity prediction, subject to water-soluble salts content in irrigation water and SAR indicator after elaborated linear regression model, $\mathrm{kg}$

\begin{tabular}{|c|c|c|}
\hline True values & Predicted values & Residuals \\
\hline 2.009 & 2.023 & +0.014 \\
\hline 1.220 & 1.222 & +0.002 \\
\hline 1.892 & 1.874 & -0.018 \\
\hline 1.450 & 1.456 & +0.006 \\
\hline
\end{tabular}


iour, when irrigated with saline water in "winter wheat - maize" cropping rotation, no significant reduction in winter wheat yield, compared to optimum mineralized water irrigation, was recorded. Then again, the authors stressed, to avoid aggressive salt accumulation in soil, it is well worth to interchange thsaline and fresh water irrigation (Liu et al., 2016). By some accounts, the maize irrigation with water high in water-soluble salts did not decrease its yield and even increased the proteins content in it to $9.1 \%$ (Leogrande et al., 2016). Thus, the irrigation with salt-saturated water is still open to question and unresolved. The problem of reutilizing waste water, as well as drainage and escape water, of various origins, is a largely unmet challenge. Some authors mention the results, which are illustrative of significant deterioration of crops yield and quality, due to irrigating with untreated sewage. In particular, it was found that irrigation with urban waste causes conspicuous retrogression in rice yield and quality (Alghobar and Suresha, 2016). Other authors point out the nutritive quality of waste water. There are findings, which verify the beneficial effect for irrigating maize, white cabbage, cauliflower, eggplants, etc. with sewage, containing a great amount of nutritional chemicals (Khan and Shaukat, 2008). The rice irrigation system drainage and escape water, which was under our study, had a low nutritive value. The greenhouse trials, which we have carried out to study maize behaviour, when irrigated with water of miscellaneous quality, serve to update the existing scientific insights into the scientific question under discussion. As to our developed regression model for maize herbage, depending on the content of water-soluble salts and SAR in agricultural water, it is meant to contribute to mathematical modelling of cropping capacity, subject to irrigation water quality, initiated by different research workers (Childs and Hanks, 1975; Letey et al., 1985; Letey and Dinar, 1986; Mok et al., 2014).

\section{CONCLUSIONS}

Greenhouse trials findings proved the maize indicator crop (Zea mays $L$.) to be of significantly lower producing capacity with water containing a great amount of water-soluble salts. It was found that the maximum maize herbage yield loss was caused by hydrocarbonate ions. Rice irrigation systems drainage and escape water turned out to be of satisfactory quality by agronomical standards, as well as of certain nutritive quality. Employment of rice irrigation system drainage and escape water (both as is and upgraded with highest quality water) for agricultural irrigation offers great opportunities, since its utilization will be facilitated, and at the same time water consumption and crop production efficiency will be improved. Needless to say, the greenhouse trials cannot incorporate the full scope of specific irrigation features in a production environment. For this reason, from now on, in order to develop best practices, there is a need to study the behaviour pattern of indicator crops, influenced by irrigation systems drainage and escape water, under field conditions.

\section{REFERENCES}

1. Andriolo J.L., da Luz G.L., Witter M.H., Godori R.S., Barros G.T. and Bortolotto O.C. 2005. Growth and yield of lettuce plants under salinity. Hortic Braz. 23:931-934.

2. APHA. 1995. Standard methods for the examination of water and waste water. 19th Ed. American Public Health Association, Washington DC.

3. Ayers R.S. and Westcott D.W. 1985. Water quality for agriculture, FAO irrigation and drainage paper 29. Rev. 1. Food and Agriculture Organization of the United Nations, Rome.

4. Banjaw D.T., Megersa H.G. and Lemma D.T. 2017. Effect of water quality and deficit irrigation on tomatoes yield and quality: a review. Adv Crop Sci Tech. 5:295.

5. Cui Y.L., Li Y.H. and Mao Z. 1998. The crop-water production function with the influence of reference evapotranspiration taken into account. J Hydraul Eng. 3:48-56.

6. Feizi M., Hajabbasi M.A. and Mostafazadehfard B. 2010. Saline irrigation water management strategies for better yield of safflower (Carthamus tinctorius L.) in an arid region. Aust J Crop Sci. 4:408-414.

7. Kelly W.P. 1963. Use of saline irrigation water. Soil Sci. 95(4):355-391.

8. Khan M.A. and Shaukat S.S. 2008. Economic benefits from irrigation of maize with treated effluent of waste stabilization ponds. Pak J Bot. 40:1091-1098.

9. Kim H., Jeong H., Jeon J. and Bae S. 2016. Effects of irrigation with saline water on crop growth and yield in greenhouse cultivation. Water. 8:127.

10. Leogrande R., Vitti C., Lopedota O., Ventrella D. and Montemurro F. 2016. Effects of irrigation vol- 
ume and saline water on maize yield and soil in Southern Italy. Irrig Drain. 65:243-253.

11. Letey J. and Dinar A. 1986. Simulated crop-water production functions for several crops when irrigated with saline waters. Hilgardia. 54:1-32.

12. Letey J., Dinar A. and Knapp K.C. 1985. Crop-water production function model for saline irrigation waters. Soil Sci Soc Am J. 49:1005-1009.

13. Lykhovyd P.V., Kozlenko Ye.V. (2018). Assessment and forecast of water quality in the River Ingulets irrigation system. Ukr J Ecol. 8(1):350-355.

14. Childs S.W. and Hanks R.J. 1975. Model of soil salinity effects on crop growth. Soil Sci Soc Am J. 39:617-622.

15. Li Y.H. 2001. Research and practice of water-saving irrigation for rice in China. Proc. of the international workshop on water saving irrigation for rice, 1-9.

16. Liu X., Til F., Chen S., Shao L., Sun H. and Zhang X. 2016. Effects of saline irrigation on soil salt accumulation and grain yield in the winter wheatsummer maize double cropping system in the low plain of North China. J Integr Agric. 15:2886-2898.

17. Lu G.A. 2000. Impact of water saving irrigation on uptake efficiency of phosphorus nutrient by rice. Irrig Drain. 19:16-20.

18. Alghobar M.A. and Suresha S. 2016. Effect of wastewater irrigation on growth and yield of rice crop and uptake and accumulation of nutrient and heavy metals in soil. Appl Ecol Environ Sci. 4:53-60.

19. Mok H.F., Dassanayake K.B., Hepworth G. and Hamilton A.J. 2014. Field comparison and crop production modelling of sweet corn and silage maize (Zea mays L.) with treated urban wastewater and freshwater. Irrig Sci. 32:351-368.
20. Oron G., DeMalach Y., Gillerman L., David I. and Rao V.P. 1999. Improved saline-water use under subsurface drip irrigation. Agric Water Manag. 39:19-33.

21. Ould Ahmed B.A., Yamamoto T. and Inoue M. 2007. Response of drip irrigated sorghum varieties growing in dune sand to salinity levels in irrigation water. J Appl Sci. 7:1061-1066.

22. Rameshwaran P., Tepe A., Yazar A. and Ragab R. 2015. The effect of saline irrigation water on the yield of pepper: experimental and modelling study. Irrig Drain. 64:41-49.

23. Rengasamy P. 2010. Soil processes affecting crop production in salt-affected soils. Funct Plant Biol. 37:613-620.

24. Tarjuelo J.M., De-Juan J.A., Moreno M.A. and Ortega J.F. 2010. Review. Water resources deficit and water engineering. Span J Agric Res. 8:102-121.

25. Wan S., Y. Kang, D. Wang and Liu S.P. 2010. Effect of saline water on cucumber (Cucumis sativus L.) yield and water use under drip irrigation in North China. Agric Water Manag. 98:105-113. Kang Y., Wang D., Liu S.P. and Feng L.P. 2007. Effect of drip irrigation with saline water on tomato (Lycopersicon esculentum Mill.) yield and water use in semi-humid area. Agric Water Manag. 90:63-74.

26. Wang X., Yang J., Liu G., Yao R. and Yu S. 2015. Impact of irrigation volume and water salinity on winter wheat productivity and soil salinity distribution. Agric Water Manag. 149:44-54.

27. Wilcox L.V. 1955. Classification and use of irrigation water. In: Circular No. 969. US Department of Agriculture, Washington. 